\title{
KARNOPRAWNA ODPOWIEDZIALNOŚĆ SPRAWCÓW PRZESTĘPSTW PRZECIWKO DOBROM KULTURALNYM POPELNIONYCH W OKRESIE KONFLIKTU ZBROJNEGO JAKO ELEMENT MIĘDZYNARODOWEJ OCHRONY ŚWIATOWEGO DZIEDZICTWA KULTURALNEGO
}

I. W 1992 r. Paweł Pawlikowski na zlecenie telewizji BBC przygotował znakomity dokument Serbski epos, w którym przedstawił dziesięć dni z życia ówczesnego przywódcy bośniackich Serbów Radovana Karadžicia. Film powstał w początkowym okresie konfliktu w Bośni i ukazał już wtedy Karadžicia, jako negatywnego bohatera wojny na Bałkanach, ale z interesującą przeszłością byłego psychiatrę w jednym z największych szpitali w Sarajewie, stypendystę Uniwersytetu Columbia, popularnego ludowego barda lekceważonego przez intelektualistów ${ }^{1}$. Kilka dekad później, 24 marca 2016 r., Międzynarodowy Trybunał Karny dla byłej Jugosławii (MTKJ) skazał bośniackiego przywódcę na karę 40 lat pozbawienia wolności, uznając go winnym jedenastu zarzutów, z których: dwa stanowiły zbrodnie ludobójstwa, pięć - zbrodnie przeciwko ludzkości, cztery - zbrodnie przeciwko prawom i zwyczajom wojennym. W opisie ostatnich $\mathrm{z}$ wymienionych wskazano m.in. na celowe niszczenie obiektów o znaczeniu kulturalnym i religijnym, np. w Novim Gradzie, Bijeljinie, Rogaticy, Sokolacuz i Zvorniku². W uzasadnieniu wspomnianego wyroku jednoznacznie podkreślono, iż zgromadzony materiał dowodowy nie pozostawił żadnych wątpliwości, że zniszczenia wspomnianych obiektów dokonane zostały celowo, bez żadnego uzasadnienia militarnego, co wypełnia znamiona zbrodni określonej w treści art. 3 lit. d Statutu MTKJ ${ }^{3}$.

Data zdarzeń dla osądzenia Karadžicia wyłączyła jurysdykcję MTK, ale charakter i przebieg konfliktu na Bałkanach w latach dziewięćdziesiątych XX w. kreowany w znacznej mierze przez ówczesnego wojskowego przywódcę bośniackich Serbów w istotnym stopniu wpłynął na ocenę międzynarodowe-

1 Por. J. Pawlicki, Guślarz ludobójstwa, „Newsweek” 2016, nr 15, z 4-10 kwietnia 2016 r., s. $58-61$.

${ }^{2}$ Wyrok ICTY z 24 marca 2016 r. w sprawie R. Karadžić, MICT-13-55.

3 Wcześniej zarzut zniszczenia obiektów o znaczeniu historycznym, kulturalnym, religijnym, artystycznym i naukowym postawiono m.in. wobec M. Jokicia i P. Strugara odpowiedzialnych m.in. za zbombardowanie starej części Dubrownika. W wyroku ICTY z 30 sierpnia 2005 r., IT-01-42-1S - M. Jokić został skazany na karę 7 lat pozbawienia wolności. Wyrokiem ICTY z 31 stycznia 2005 r. (I Izba Orzecznicza) i 17 czerwca 2008 r. (Izba Apelacyjna) IT-01-42 P. Strugar został skazany na karę 7 lat i 6 miesięcy pozbawienia wolności. 
go poziomu prawnej ochrony dóbr kulturalnych w okresie konfliktu zbrojnego, gdyż ujawnił jej iluzoryczność. Paraliż przyjętego wzorca prawnej ochrony dziedzictwa kulturowego pojawił się bowiem przy braku dobrowolnego przestrzegania przez strony konfliktu standardów ochrony, a wydawało się, że poziom intelektualny i wykształcenie współczesnych przywódców (przynajmniej w przestrzeni euroatlantyckiej) będzie dostatecznym gwarantem przestrzegania wspomnianych standardów, według których dobro kulturalne stanowi odrębną kategorię, nieklasyfikowaną na podstawie kryteriów własności lub przynależności etnicznej, ale chronioną w świetle ponadnarodowej idei autonomii sztuki. Tymczasem przykład Karadžicia i skupionej wokół niego serbskiej generalicji ukazał zupełnie odmienny stan rzeczy, nawiązujący do prymitywnych reguł uprawniających najeźdźców lub zwycięzców do grabienia i dewastowania podbitego terytorium.

W efekcie u schyłku minionego stulecia społeczność międzynarodowa stanęła przed potrzebą uruchomienia nowych form prawnych w celu zapewnienia bezpieczeństwa dobrom kulturalnym w czasie konfliktów zbrojnych. W podnoszonych postulatach wskazywano m.in. na potrzebę doprecyzowania kwestii indywidualnej odpowiedzialności karnej sprawców naruszeń i zaostrzenia grożących z tego tytułu sankcji ${ }^{4}$. Skutki konfliktu na Bałkanach przesądzały o słuszności zgłaszanych postulatów. W tym celu, z jednej strony, dostrzegano więc konieczność weryfikacji w tym kierunku postanowień Konwencji z 1954 r., z drugiej - orzecznictwo MTKJ, a także niektórych paratrybunałów międzynarodowych ${ }^{5}$ przekonywało o zasadności objęcia tego rodzaju czynów jurysdykcją MTK. W ten oto sposób na tle znanego dotychczas problemu międzynarodowej ochrony dóbr kulturalnych w okresie konfliktu zbrojnego usamodzielniono odrębną kwestię ścigania sprawców przestępstw przeciwko dobrom kulturalnym popełnionych w okresie konfliktu zbrojnego.

II. Na poziomie aktywności legislacyjnej UNESCO realizacja przyjętej koncepcji nastapiła przez uzupełnienie postanowień Konwencji z 1954 r., do której dołączony został Drugi protokół, otwarty do podpisu 17 maja 1999 r. (Polska przyjęła go 29 lipca 2011 r. $)^{6}$. Przygotowanie w ramach współpracy państw

\footnotetext{
${ }^{4}$ Por. Final Report of the Commission of Experts Established Pursuant to Security Council Resolution 780(1992), UN doc. S/1994/674/, Annex IX, vol. V.

${ }^{5} \mathrm{~Np}$. w przyjętych przez Komisję Claimsa 12 grudnia 2000 r. w Algierze umowach kończących konflikt miedzy Erytreą i Etiopią (lata 1998-2000) stwierdzono, że Etiopia ponosi odpowiedzialność za świadome zniszczenia obiektów o wielkim znaczeniu historycznym dla Erytrei, czym naruszyła zasady ochrony dóbr kulturalnych w okresie konfliktu zbrojnego, jakie wyrażone zostały w Konwencji haskiej z 1954 r. Brak trybunału o międzynarodowej jurysdykcji uniemożliwił wówczas pociagnięcie do odpowiedzialności karnej osób odpowiedzialnych za te zbrodnie. Zob. F. Francioni, The evolving framework for the protection of cultural heritage in international law, w: S. Borelli, F. Lenzrini (eds.), Cultural Heritage, Cultural Rights, Cultural Diversity. New Developments in International Law, Leiden 2012, s. 11.

${ }^{6}$ Drugi protokół do Konwencji o ochronie dóbr kulturalnych w razie konfliktu zbrojnego podpisanej w Hadze dnia 14 maja 1954 r., sporządzony w Hadze dnia 26 marca 1999 r., wszedł w życie 24 marca 2004 r., w trzy miesiące po złożeniu dwudziestego dokumentu ratyfikacji, Dz. U. 2012, poz. 248 (dalej jako: II Protokół do Konwencji z 1954; sama Konwencja haska z 1954 r. - dalej jako: Konwencja z 1954).
} 
sygnatariuszy Konwencji z 1954 wspomnianego dokumentu nie miało charakteru przypadkowego - poprzedził go raport oceniający dotychczasowe funkcjonowanie Konwencji z 1954; jego opracowanie zlecił dyrektor generalny UNESCO, a przygotował go Patrick J. Boylan w 1993 r. $^{7}$

Wśród postanowień II Protokołu do Konwencji z 1954 uwagę zwraca zwłaszcza rozdział IV, dotyczący odpowiedzialności karnej i jurysdykcji. Dotychczas kwestia odpowiedzialności karnej osób z tytułu naruszenia postanowień Konwencji z 1954 była raczej lakonicznie ujęta w jej art. 28, oznaczonym jako „Sankcje”. Z treści wskazanego przepisu wynika przyjęcie przez umawiające się strony zobowiązania do uwzględnienia w systemach poszczególnych państw środków, za pomocą których możliwe byłoby wymierzenie sankcji karnych lub dyscyplinarnych wobec osób, które dopuściły się naruszenia postanowień Konwencji z 1954 lub nakazały ich naruszenie, przy czym podjęcie ścigania powinno nastapić bez względu na obywatelstwo sprawcy. Nie sformułowano katalogu czynów skutkujących odpowiedzialnością karną lub dyscyplinarna, a zatem naruszenia Konwencji określane sa zgodnie z jej poszczególnymi postanowieniami. Konstrukcja omawianego przepisu zbieżna jest z regulacjami zawartymi w konwencjach genewskich, a zwłaszcza z art. 146 IV Konwencji genewskiej ${ }^{8}$.

Rodzaj i wysokość sankcji grożących z tytułu popełnienia czynów skierowanych przeciwko dobrom kulturalnym w okresie konfliktu zbrojnego uzależnione są więc od rozwiązań krajowych, co utrudnia formułowanie w tym przedmiocie ogólnych wniosków. Sytuację komplikuje nadto fakt, że penalizując - zgodnie z zaleceniem art. 28 Konwencji z 1954 - wskazane powyżej zachowania, w systemach krajowych nie zawsze przyjmowano konwencyjna definicję dobra kulturalnego, nierzadko zastępowano ja pojęciem stworzonym na potrzeby rodzimego prawa karnego lub pojęciem dobra kultury, które w ujęciu międzynarodowym definiowane jest przez art. 1 Konwencji dotyczącej środków zmierzających do zakazu i zapobiegania nielegalnemu przywozowi, wywozowi i przenoszeniu własności dóbr kultury9 . Odwołanie takie jest kontrowersyjne, a to przede wszystkim dlatego, że pojęcie „dobro kultury”, o którym mowa w art. 1 Konwencji dotyczącej środków zmierzających do zakazu i zapobiegania nielegalnemu przywozowi, wywozowi i przenoszeniu własności dóbr kultury, zgodnie z jej celem ograniczone zostało wyłącznie do kategorii ruchomości.

${ }^{7}$ Wybór P.J. Boylana wiązał się w znacznej mierze z pełnioną przez niego funkcją przewodniczącego ICOM. Wyniki raportu poddano analizie w 1994 r. na spotkaniu ekspertów prawnych, kulturalnych i rządowych sygnatariuszy Konwencji z 1954 w Lauswolt, gdzie też przyjęto dokument końcowy, który został zrewidowany po uwzględnieniu propozycji zgłoszonych przez uczestników paryskich spotkań z 1995 i 1997 r. oraz spotkania w Wiedniu w 1998 r. Zob. P.J. Boylan, Review of the Convention for the Protection of Cultural Property in the Event of Armed Conflict (The Hague Convention of 1954), UNESCO doc. CLT-93/WS/12, Paris 1993.

${ }^{8}$ Konwencja genewska o ochronie osób cywilnych podczas wojny, podpisana w Genewie 12 sierpnia 1949 r., Dz. U. 1956, Nr 38, poz. 171, załącznik.

${ }^{9}$ Konwencja dotycząca środków zmierzających do zakazu i zapobiegania nielegalnemu przywozowi, wywozowi i przenoszeniu własności dóbr kultury sporządzona w Paryżu 17 listopada 1970 r. (Dz. U. 1974, Nr 20, poz. 106). 
Ostatecznie jednak lakoniczne sformułowania zawarte w art. 28 Konwencji z 1954 nie powinny dziwić, odzwierciedlają one bowiem funkcjonujaca w XX w. praktykę stanowienia norm prawa międzynarodowego co do modelu kształtowania wielostronnych umów międzynarodowych w przedmiocie kompetencji karnej na poziomie minimum, tzn. tylko przez generalne zakreślenie ram kompetencyjno-jurysdykcyjnych państwa ${ }^{10}$.

Na tym tle zwraca z kolei uwage problem jurysdykcji. Zgodnie z najczęściej przywoływaną w prawie międzynarodowym definicją pojęcia ,jurysdykcja” rozumie się przez nią prawo państwa do wkraczania w sferę praw i obowiązków ludzi czy tė̇ regulowania ich zachowania w sprawach niemajacych wyłacznie charakteru wewnętrznego (krajowego) ${ }^{11}$. Z karnoprawnej perspektywy trzeba doprecyzować nadto, że pojęcie to funkcjonuje przede wszystkim w obszarze prawa karnego procesowego. Do podjęcia ścigania karnego konieczne jest istnienie jurysdykcji państwa, która stanowi jedna z dodatnich przesłanek procesowych, decydujących o możliwości prowadzenia postępowania karnego. Na gruncie polskiej procedury karnej przesłankę tę określa art. $17 \S 1$ pkt 8 k.p.k. ${ }^{12} \mathrm{~W}$ doktrynie pojęcie jurysdykcji w sprawach karnych definiuje się jako: uprawnienie organów danego państwa do rozpoznawania i rozstrzygania spraw o przestępstwa na podstawie jego ustawodawstwa karnego wraz z wykonywaniem orzeczonych kar lub środków karnych, całokształt ustawodawstwa karnego stanowi materialną podstawę jurysdykcji ${ }^{13}$. Artykuł 28 Konwencji z 1954, zobowiąując państwa strony do przyjęcia stosownych środków penalnych, równocześnie nakazuje objęcie ściganiem sprawców naruszeń bez względu na ich obywatelstwo. Jeśli przyjąc taką formułę, w ujęciu międzynarodowym wzrasta znaczenie reguły ne bis in idem, która nie tyle ułatwia rozstrzyganie sporów jurysdykcyjnych, ile zabezpiecza sprawcę przed możliwością wielokrotnego ponoszenia odpowiedzialności z tytułu popełnienia danego czynu, w obrębie jurysdykcji różnych państw. Problem ten aktualizuje się zwłaszcza w odniesieniu do naruszeń penalizowanych w systemach wewnętrznych poszczególnych państw sygnatariuszy zgodnie ze zobowiąaniami wynikajacymi z art. 28 Konwencji z 1954. We współczesnych demokracjach reguła ne bis in idem traktowana jest jako jeden z fundamentalnych składników systemu krajowego prawa karnego i stanowi jedną z podstawowych gwarancji oskarżonego. Na poziomie uniwersalnym zaliczono ją do katalogu niezbywalnych praw człowieka i gwarantowana jest przez art. 14 pkt 7 Międzynarodowego paktu praw obywatelskich i politycznych ${ }^{14}$.

10 Szerzej Z.S. Feller, La resolution des conflits de juridiction en matiere penale, „Revue Internationale de Droit Pènale" (RIDP) 1974.

11 Szerzej F.A. Mann, The doctrine of jurisdiction in international law, „Recueil des Cours de l'Academie de droit international Law" (RCADI) 111, 1964, s. 9-162.

${ }^{12}$ Ustawa z 6 czerwca 1997 r. - Kodeks postępowania karnego (t.pierwot.: Dz. U. 1997, Nr 89, poz. 555 ze zm.; t.jedn.: Dz. U. 2017, poz. 1904).

${ }^{13}$ Por. M. Płachta, Konflikty jurysdykcyjne w sprawach karnych: pojęcie, geneza $i$ środki zaradcze, „Prokuratura i Prawo” 2010, z. 11, s. 8.

${ }^{14}$ Międzynarodowy pakt praw obywatelskich i politycznych przyjęty przez Zgromadzenie Ogólne ONZ 19 grudnia 1966 r. (Dz. U. 1977, Nr 38, poz. 167, załącznik). 
Przepisy rozdziału IV zawarte w II Protokole do Konwencji z 1954 przyczyniły się do wyeliminowania niektórych z wskazanych powyżej kontrowersji, ale też i ujawniły nowe. Pozytywnie ocenić należy przede wszystkim sformułowanie w art. 15 ust. 1 II Protokołu katalogu umyślnych przestępstw przeciwko dobrom kulturalnym naruszających postanowienia Konwencji z 1954 lub jej II Protokołu. Wymieniono pięć kategorii czynów, jakich może dopuścić się sprawca, dwie spośród nich dotyczą dóbr kulturalnych objętych ochrona wzmocniona, tj.: atak na dobro kulturalne oraz wykorzystanie dobra kulturalnego lub jego najbliższego otoczenia do wsparcia działań wojskowych (art. 15 ust. 1 lit. a-b). Kolejne trzy kategorie czynów dotyczą pozostałych dóbr kulturalnych i polegają na: spowodowaniu rozległych zniszczeń lub zawłaszczeniu dobra kulturalnego, objęciu go atakiem, dokonaniu kradzieży, rabunku lub przywłaszczenia bądź popełnieniu przeciw niemu aktu wandalizmu (art. 15 ust. 1 lit. d-c). Przyjęty katalog przestępstw również nawiązał do postanowień konwencji genewskich i ich protokołów dodatkowych z 1977 r. ${ }^{15}$

Aby właściwie porównać regulacje przyjęte w Statucie MTK ${ }^{16}$ z treścia art. 15 II Protokołu do Konwencji z 1954 warto zwrócić uwagę na jego konstrukcję. W tym kontekście istotne znaczenie należy przypisać nie tylko przyjętej w art. 10 II Protokołu nowej koncepcji tzw. ochrony wzmocnionej, lecz także funkcjonującym dotychczas formom ochrony, tj. ogólnej (art. 2 Konwencji z 1954) i specjalnej (art. 8 Konwencji z 1954), ponieważ współokreślaja one znamiona przestępstw wymienionych w art. 15 II Protokołu do Konwencji z 1954. Problem ten ma szczególne znaczenie zwłaszcza na gruncie postanowień Statutu MTK, w którym wśród zbrodni związanych z zniszczeniem i dewastacją budynków cywilnych w sposób wyjątkowy potraktowano tylko budynki objęte ochroną specjalną lub wzmocnioną.

W zakresie możliwości egzekwowania odpowiedzialności karnej istotne znaczenie posiada z kolei art. 16 II Protokołu dotyczący jurysdykcji, w którym potwierdzono obowiąywanie zasady jurysdykcji uniwersalnej. W przypadku przestępstw popełnionych wobec obiektów objętych ochroną wzmocniona, a nadto określonego w art. 15 ust. 1 lit. $\mathrm{c}^{17}$, zasada ta ma charakter obligatoryjny, a art. 18 II Protokołu do Konwencji z 1954 zastrzega wobec sprawców takich czynów obowiązek ekstradycji, zgodnie z regułą aut dedere aut iudicare.

Ocena znaczenia przyjętych rozwiązań pozwala stwierdzić, że skuteczność ich egzekwowania uzależniona jest wyłącznie od sposobu wdrożenia do systemów krajowych. W polskim kodeksie karnym ${ }^{18}$ art. $125 \S 1$ przewiduje

${ }^{15}$ Por. J. Toman, The Protection of Cultural Property in the Event of Armed Conflict, Dartmouth 1996, s. 293-294.

${ }^{16}$ MTK powołany został w Rzymie z 17 na 18 lipca 1998 r. przez przyjęcie Statutu MTK (określanego też jako Statut Rzymski MTK), w czasie odbywającej od 15 czerwca do 17 lipca 1998 r. Konferencji Dyplomatycznej Pełnomocników Rządów w sprawie powołania Międzynarodowego Trybunału Karnego. Szerzej M. Płachta, Międzynarodowy Trybunał Karny, t. 1, Kraków 2004, s. 118-262.

${ }^{17}$ Czyli: zniszczenie lub zawłaszczenie dobra kulturalnego objętego ochroną na mocy Konwencji z 1954 r. lub jej Protokołu II.

${ }_{18}$ Ustawa z 6 czerwca 1997 r. - Kodeks karny (t.pierwot.: Dz. U. 1997, Nr 88, poz. 553 ze zm.; t.jedn.: Dz. U. 2016, poz. 1137 ze zm.). 
odpowiedzialność karną osób, które na obszarze okupowanym, zajętym lub na którym toczą się działania zbrojne, naruszając prawo międzynarodowe, niszcza, uszkadzają lub zabierają dobro kultury, co zagrożone jest kara pozbawienia wolności od roku do lat 10. Jeżeli natomiast czyn dotyczy mienia znacznej wartości lub dobra mającego szczególne znaczenie dla kultury, sprawca podlega karze pozbawienia wolności na czas nie krótszy od lat 3 (art. $125 \S 2$ k.k.). Kodeks karny nie uniknął zatem wspomnianych powyżej kontrowersji, gdyż używa w art. $125 \S 1$ terminu „dobro kultury”, ale nie wprowadza jego odrębnej definicji legalnej. Krytyczne uwagi nasuwa również konstrukcja zbrodni określonej w art. $125 \S 2$ k.k., przede wszystkim ze względu na wykorzystanie w niej pojęcia „mienie znacznej wartości”"19. W ten sposób polski ustawodawca odstapił bowiem od przyjętej w Konwencji z 1954 koncepcji ochrony dóbr kulturalnych, która obejmuje dobra o szczególnym znaczeniu dla kultury, a jej wyznacznikiem nie jest zwykła wartość rynkowa w cywilnoprawnym ujęciu, ale wartość uniwersalna, nieoszacowana, tworzona przez posiadane przez nie wyjątkowe walory ważne z punktu widzenia historii i szeroko pojętego rozwoju ludzkości, co jednoznacznie wynika z Preambuły do Konwencji z 1954 oraz przyjętej w jej art. 1 definicji dobra kulturalnego ${ }^{20}$. Treść art. $125 \S 2$ k.k. zbliżona jest zatem bardziej do sposobu penalizacji zachowań godzacych w dobra kulturalne, wyznaczonych postanowieniami Statutu MTK, co zasadniczo nie powinno dziwić, gdyż wspomniane przepisy do Kodeksu karnego wprowadzone zostały jako zobowiązania wynikłe z przyjęcia przez Polskę Statutu MTK.

III. Analizując z kolei treść Statutu MTK w kontekście realizacji postulatu wzmocnienia międzynarodowej ochrony dóbr kulturalnych w okresie konfliktu zbrojnego, przez możliwość przypisania indywidualnej odpowiedzialności karnej sprawców czynów skierowanych przeciwko tego rodzaju dobrom, warto raz jeszcze podkreślić, że przyjęte regulacje nie kreują rozwiązań dotyczacych organizacji ani zasad wspomnianej ochrony. Postanowienia Statutu MTK umożliwiaja jedynie ściganie i osądzenie sprawców przestępstw przeciwko dobrom kulturalnym popełnionym w okresie konfliktu zbrojnego. Nadto

${ }^{19}$ Definicja legalna „mienia znacznej wartości” sformułowana została w art. 115 § 5 k.k., zgodnie z którym mieniem znacznej wartości jest mienie, którego wartość w czasie popełnienia czynu zabronionego przekracza $200000 \mathrm{zł}$.

${ }^{20}$ W rozumieniu Konwencji z 1954 za dobra kulturalne uważa się bez względu na ich pochodzenie oraz na osobę właściciela: a) dobra ruchome lub nieruchome, które posiadają wielką wagę dla dziedzictwa kulturalnego narodu, np. zabytki architektury, sztuki lub historii zarówno religijne, jak i świecki; stanowiska archeologiczne; zespoły budowlane posiadające jako takie znaczenie historyczne lub artystyczne, dzieła sztuki, rękopisy, książki i inne przedmioty o znaczeniu artystycznym, historycznym lub archeologicznym, jak również zbiory naukowe i poważne zbiory książek, archiwaliów lub reprodukcji wyżej określonych dóbr; b) gmachy, których zasadniczym i stosowanym w praktyce przeznaczeniem jest przechowywanie lub wystawianie dóbr kulturalnych ruchomych określonych pod lit. a, np.: muzea, wielkie biblioteki, składnice archiwalne, jak również schrony mające na celu przechowywanie w razie konfliktu zbrojnego dóbr kulturalnych ruchomych określonych pod lit. a; c)ośrodki obejmujące znaczną ilość dóbr kulturalnych określonych pod lit. a i b. 
w Statucie MTK nie zawarto żadnego przepisu dotyczącego wyłącznie ścigania przestępstw przeciwko dobrom kulturalnym, jak również nie wykorzystano pojęcia „dobro kulturalne”. W tym też zakresie Statut MTK utrzymał dotychczasową tendencję widoczną w pierwszych konwencjach haskich (zwłaszcza z $1907 r{ }^{21}$ ) oraz wspomnianej Konwencji genewskiej z 1949 r. i konsekwentnie brak w nim odniesień do przyjętej 1954 r. Konwencji o ochronie dóbr kulturalnych w razie konfliktu zbrojnego. W literaturze natomiast jednoznacznie podkreśla się, że brak współpracy między grupami autorów przygotowujących II Protokół do Konwencji z 1954 i Statut MTK spowodował, że nie zostały wyeliminowane wszystkie dotychczas istniejace luki prawne w zakresie ścigania sprawców przestępstw przeciwko dobrom kulturalnym w okresie konfliktu zbrojnego ${ }^{22}$. Osiagnięty stan prawny nie spełnia zatem w pełni pokładanych w nim przez społeczność międzynarodową oczekiwań, co niewątpliwie rozczarowuje, zważywszy, że oba dokumenty powstały po około czterdziestoletnim okresie obowiązywania Konwencji z 1954. Niemniej istotne jest, że jurysdykcją MTK zostały objęte cztery przestępstwa uznane za najpoważniejsze zbrodnie międzynarodowe: zbrodnia ludobójstwa, zbrodnie przeciwko ludzkości, zbrodnie wojenne, zbrodnia agresji (art. 5 ust. 1 Statutu MTK).

Czyny zagrażajace dobrom kulturalnym klasyfikowane sa jako zbrodnie wojenne i w przypadku konfliktu zbrojnego o charakterze międzynarodowym wskazane zostały w art. 8 ust. 2 lit. b jako: zamierzone kierowanie ataków na budynki przeznaczone na cele religijne, edukacyjne, artystyczne, naukowe lub charytatywne, pomniki historyczne, szpitale oraz miejsca, gdzie gromadzeni sa ranni chorzy, pod warunkiem że nie są one celami wojskowymi (pkt ix). Zwraca uwagę, że tylko wskazany przepis rzeczywiście uwzględnia walory, które potwierdzaja potrzebę uruchomienia ochrony wartością obiektów z uwagi na ich znaczenie dla światowego dziedzictwa kulturalnego. Niemniej warto odnotować także regulacje, które co prawda dotyczą w sposób ogólny niszczenia lub zagarniania własności nieprzyjaciela z wyjątkiem przypadków, gdy takiego zniszczenia lub zagarnięcia wymaga konieczność wojskowa (pkt xiii) oraz wydawania na łup miast lub miejsc nawet zdobytych szturmem (pkt xvi), gdyż zachowania takie są nie tylko charakterystyczne dla konfliktów zbrojnych, ale ze względu na możliwość uzyskania dużej korzyści majątkowej lub z powodów ideologicznych bardzo często kierowane są przeciwko dobrom o znaczeniu dla światowego dziedzictwa kulturalnego. Dlatego też należy ubolewać, że nie zostały one objęte regulacją dotyczącą obiektów o szczególnym znaczeniu dla światowego dziedzictwa kulturalnego.

${ }^{21}$ W 1907 r. przyjęto: IV konwencję opisująca prawa i zwyczaje wojenne oraz IX dotyczącą bombardowania przez siły morskie w czasie pokoju. Sformułowano wówczas regułę zakazu niszczenia lub zajmowania własności nieprzyjacielskiej oraz jej grabienia, a także wprowadzono pojęcie mienia uprzywilejowanego, którym objęto m.in. budynki poświęcone obrzędom religijnym, sztuce, nauce, dobroczynności, szpitale oraz zabytki historyczne (art. 27, art. 56 IV Konwencja). Zakaz niszczenia nie znajdował jednak zastosowania, jeżeli działania te uzasadniała konieczność wojskowa (art. 23, 24 IV Konwencja). Szerzej R. O’Keefe, The Protection of Cultural Property in Armed Conflict, Cambridge 2006, s. 22-27.

${ }^{22}$ M. Frulli, The criminalization of offences against cultural heritage in times of armed conflict: the quest for consistency, „The Journal of International Law” 22(1), 2011, s. 204. 
Nadto trzeba zauważyć, że jak jednoznacznie wynika z treści art. 8 ust. 2 lit. b pkt ix Statutu MTK dotyczy on nieruchomości ${ }^{23}$, dopiero przy wykładni art. 8 ust. 2 lit. b pkt xiii oraz ix Statutu MTK w sposób nieco zakamuflowany ujawnia się także kwestia ochrony ruchomości, ponieważ w zasadzie tylko one ze względu na swą istotę mogą stanowić przedmiot „łupu” i „zagarnięcia”, aczkolwiek nie można wykluczyć również możliwości demontażu nieruchomości, np. w celu przeniesienia jej na terytorium agresora. Tym bardziej postulat penalizacji czynów opisanych w art. 8 ust. 2 lit. b pkt xiii oraz ix Statutu MTK, a skierowanych przeciwko dobrom o szczególnym znaczeniu dla dziedzictwa światowego jest uzasadniony.

Zwraca również uwagę, że o ile w art. 8 Statutu MTK karnoprawną ochroną objęto szeroki zakres przedmiotów i dóbr, o tyle oczywiste jest, że w stosunku do niektórych z nich ochrona ta się dubluje, a problem ten aktualny jest także w odniesieniu do obiektów istotnych dla ochrony dziedzictwa kulturalnego. Wystarczy bowiem spojrzeć na art. 8 ust. 2 lit. a Statutu MTK, w którym penalizacją objęto: poważne zniszczenia i przywłaszczenia mienia, nieusprawiedliwione koniecznością wojskową i dokonane bezprawnie i samowolnie (pkt iv); zamierzone kierowanie ataków na obiekty cywilne, czyli obiekty niebędące celami wojskowymi (pkt ii); zamierzone przeprowadzenie ataku ze świadomościa, że atak ten spowoduje przypadkowa utratę życia lub zranienie osób cywilnych lub szkodę w obiektach cywilnych lub rozległą i naturalną szkodę w środowisku naturalnym, które byłyby wyraźnie nadmierne w stosunku do konkretnej, bezpośredniej i całkowicie spodziewanej korzyści wojskowej (iv); atakowanie lub bombardowanie, przy użyciu jakichkolwiek środków bezbronnych miast, wsi, domów mieszkalnych i budowli niebędących celami wojskowymi (v). Wymienione przepisy mają na tyle szeroki zakres, że obejmuja również działania skierowane przeciwko wskazanym w art. 8 ust. 2 lit. b pkt ix budynkom przeznaczonym na cele religijne, edukacyjne, artystyczne, naukowe lub charytatywne oraz pomnikom historycznym. Z punktu widzenia indywidualizacji odpowiedzialności karnej sprawcy z tytułu popełnionych czynów przyjęta konstrukcja zyskuje jednak aprobatę, a to przede wszystkim w kontekście problemu wymiaru kary. Zgodnie bowiem z art. 78 ust. 1 Statutu MTK, wymierzając karę, Trybunał uwzględnia takie czynniki, jak ciężar zbrodni i właściwości osobiste skazanego. Jeśli przyjać zatem, że zachowania wyszczególnione w pkt 8 ust. 2 lit b pkt ix, xiii, xvi Statutu MTK stanowią lex specialis, to przy wymiarze kary moga uzasadniać słuszność jej zaostrzenia z uwagi na kategorię naruszonego mienia. Rozwiązanie to jest istotne również i z tego względu, że w Statucie MTK sankcje karne nie zostały sprecyzowane przy

${ }^{23}$ Warto przypomnieć, że koncepcja wyróżnienia nieruchomości w formie przyjętej w art. 8 ust. 2 lit. b pkt ix Statutu MTK nawiązuje do rozwiązania przyjętego w art. 3 lit. d Statutu MTKJ, w którym potrzeba ta dostrzeżona została w związku z docierającymi do społeczności międzynarodowej informacjami o zniszczeniach obiektów dziedzictwa światowego na terenie byłej Jugosławii, a zwłaszcza Starego Miasta w Dubrowniku i Biblioteki Narodowej w Sarajewie. Także i wówczas nie wykorzystano przyjętej na gruncie UNESCO koncepcji ochrony dóbr kulturalnych. 
poszczególnych zbrodniach, ale w sposób zbiorczy określa je art. 77 ust. 1 i 2 Statutu MTK ${ }^{24}$.

W kontekście niniejszych rozważań należy również podkreślić, że w art. 8 ust. 2 lit. c pkt iv oraz v Statutu MTK penalizacją objęto także zbrodnie wojenne popełnione w okresie konfliktu zbrojnego o charakterze wewnętrznym, podobne rozwiązanie przyjęto w II Protokole do Konwencji z 1954, a w szerszym ujęciu posunięcie to odzwierciedla zmiany, jakie w ostatnich dziesięcioleciach dokonały się w nauce i doktrynie prawa międzynarodowego, w tym w prawie konfliktów zbrojnych, czy szerzej ujmujacc - prawa humanitarnego. Według wskazanych powyżej przepisów Statut MTK w przypadku konfliktu o charakterze wewnętrznym podobnie, jak i w warunkach konfliktu o charakterze międzynarodowym za zbrodnie wojenne uznaje zamierzone kierowanie ataków na budynki przeznaczone na cele religijne, edukacyjne, artystyczne, naukowe lub charytatywne, pomniki historyczne oraz wydawanie na łup miast miejsc nawet zdobytych szturmem.

Oceniajac natomiast zakres jurysdykcji MTK, trzeba stwierdzić, że w art. 8 ust. 1 Statutu MTK wprowadzono klauzulę progu, za pomocą której jurysdykcja Trybunału ograniczona została do zbrodni wojennych, które popełniane sa masowo, tzn. na szeroka skalę lub w sposób zorganizowany i systematyczny, tzn. jako „realizacja planu lub polityki”. Ten ostatni z wymienionych motywów ma istotne znaczenie $\mathrm{w}$ przypadku zbrodni skierowanych przeciwko dobrom o szczególnym znaczeniu dla kultury, ponieważ z reguły wynikają one z zamiaru unicestwienia dziedzictwa narodowego przeciwnika, co potwierdza poniekąd wyrok MTK z 27 sierpnia 2016 r. w sprawie Ahmada Al Mahdiego ${ }^{25}$ o czym poniżej.

Zwraca też uwagę, że zbrodnie wojenne określone w Statucie MTK posiadają z reguły zbiorczą strukturę, a w rezultacie poszczególne czyny w ramach jednej zbrodni moga zostać popełnione przez różnych sprawców, co prowadzi do możliwości oskarżenia i skazania w ramach jednej zbrodni kilku sprawców, o ile tylko istnieje związek między konkretnym czynem a całą zbrodnią ${ }^{26}$. Sytuacja ta znajduje potwierdzenie w treści art. 25 ust. 3 lit. a Statutu MTK, z którego wynika, że odpowiedzialność karną ponosi osoba, która dopuściła się zbrodni objętej jurysdykcją Trybunału, niezależnie od tego, czy działała wspólnie czy z inną osobą albo za pośrednictwem innej osoby, bez względu na to, czy inna osoba ponosi odpowiedzialność karna. Dotychczasowa praktyka MTK unika jednak w prowadzonych postępowaniach procesowej łączności podmiotowej, inaczej niż w postępowaniu przed MTKJ. Brak złożoności podmiotowej uzasadnia jednak w pełni charakter postępowania przed MTK oraz procedury związane z ujęciem i dostarczeniem sprawców.

${ }^{24}$ W katalogu kar uwzględniono: karę pozbawienia wolności, którą wymierza się na czas oznaczony, nieprzekraczający 30 lat i karę dożywotniego pozbawienia wolności (art. 77 ust. 1 lit. a, b Statutu MTK) oraz wymierzaną obok kary pozbawienia wolności grzywnę, przepadek korzyści, majątku i aktywów pochodzących bezpośrednio lub pośrednio z przestępstwa (art. 77 ust. 2 lit. a, b Statutu MTK).

25 ICC-01/12-01/15.

26 Szerzej M. Płachta, Międzynarodowy Trybunat Karny, t. 1, s. 393. 
Na tle problemu odpowiedzialności karnej przed MTK za zbrodnie skierowane przeciwko obiektom o znaczeniu dla kultury, jakie wskazane zostały w przytoczonych powyżej jednostkach redakcyjnych art. 8 Statutu MTK, istotne znaczenie ma również kwestia wyłączenia odpowiedzialności karnej sprawcy. Budzi ona watpliwości wynikające z braku zdefiniowania w Statucie pojęć: „cel wojskowy” i „konieczność wojenna”, mimo że oba te pojęcia wykorzystane zostały do określenia znamion niektórych zbrodni w art. 8 Statutu MTK. Zarówno bowiem w odniesieniu do zbrodni popełnionych w trakcie konfliktu zbrojnego o charakterze międzynarodowym (art. 8 ust. 2 lit. b pkt ix Statutu MTK), jak i zbrodni popełnionych w trakcie konfliktu o charakterze wewnętrznym (art. 8 ust. 2 lit. c pkt iv Statutu MTK) uznano za zbrodnię wojenną działanie polegające na umyślnym kierowaniu ataków m.in. na budynki przeznaczone na cele religijne, edukacyjne, artystyczne, naukowe bądź pomniki historyczne z wyłączeniem sytuacji, gdy stanowią one cele wojskowe. Z kolei w art. 8 ust. 2 lit b pkt xiii Statutu MTK za zbrodnię uznano niszczenie lub zagarnięcie własności nieprzyjaciela, z wyłączeniem przypadków, gdy wymaga tego konieczność wojenna. Do Statutu MTK wprowadzono zatem pojęcia stanowiące od lat przedmiot dyskusji w prawie międzynarodowym ${ }^{27}$, przy czym jak dotychczas definicje legalne przyjęte zostały tylko dla „celu wojskowego”. Sformułowane one zostały w dwóch dokumentach po pierwsze w Protokole I do Konwencji genewskich z 1949 r..$^{28}$, w którym w art. 52 ust. 2 postanowiono, o ograniczeniu ataków ściśle do celów wojskowych, czyli takich, które z powodu swej natury, rozmieszczenia, przeznaczenia lub wykorzystania wnosza istotny wkład do działalności wojskowej, a których całkowite lub częściowe zniszczenie, zajęcie lub zneutralizowanie daje określoną korzyść w danej sytuacji. Po drugie trud zdefiniowania „celu wojskowego” podjęty został w art. 1 lit. f II Protokołu do Konwencji z 1954, w którym przyjęto, że cel wojskowy stanowi obiekt, który ze względu na charakter, lokalizację, cel lub zastosowanie wnosi istotny wkład do działań wojskowych i którego całkowite lub częściowe zniszczenie, zajęcie lub zneutralizowanie $\mathrm{w}$ istniejących $\mathrm{w}$ danym momencie okolicznościach przynosi określoną korzyść. Nie ulega zatem wątpliwości, że pomocniczo sędziowie MTK zmuszeni będą do wykorzystywania w prowadzonych postępowaniach przytoczonych powyżej definicji „,elu wojskowego”.

W powyższym kontekście w sposób ewidentny ujawniają się też negatywne skutki braku współpracy między autorami Statutu MTK i II Protokołu do Konwencji z 1954, która mogłaby przyczynić się do wypracowania jednolitego ładu terminologicznego. Brak stosownych postanowień w tym przedmiocie w Statucie MTK znacząco ogranicza możliwość skutecznego powoływania się w ramach obrony w toku postępowania przed Trybunałem na istnienie „celu wojskowego” bądź „konieczności wojennej”. Dodatkowo sytuację komplikuja

27 Szerzej E. Ehlert, Prosecuting the Destruction of Cultural Property in International Criminal Law. With a Case Study on the Khmer Rouge's Destruction of Cambodia Heritage, Liden-Boston 2014, s. 135-137.

28 Protokół I do Konwencji genewskich z 12 sierpnia 1949 r. dotyczących ochrony ofiar międzynarodowych konfliktów zbrojnych, sporządzony w Genewie 8 czerwca 1977 r. (Dz. U. 1992, Nr 41, poz. 175, załącznik). 
enigmatyczne sformułowania art. 31 ust. 1 lit. a-d Statutu MTK, w którym wyliczono podstawy wyłączenia odpowiedzialności karnej w razie popełnienia zbrodni wojennej, w którym oba omawiane pojęcia zostały pominięte. Co prawda w art. 31 ust. 1 lit. c Statutu MTK wskazano m.in. na przypadek, gdy sprawca podejmuje działania w obronie własności niezbędnej do wypełnienia misji wojskowej przed bezpośrednim i bezprawnym użyciem siły, w sposób proporcjonalny do stopnia niebezpieczeństwa grożącego sprawcy, innej osobie lub chronionej własności (lit. c), ale w ocenie doktryny tylko niezwykle przyjazna wykładnia pozwala ten przypadek łączyć z pojęciem „konieczności wojskowej” bądź „celu wojskowego” ${ }^{29}$. Nie ulega jednak wątpliwości, że brak precyzyjnych określeń i dualizm terminologiczny na pewno utrudnią pracę sędziów Trybunału, niemniej wypracowane orzecznictwo może przyczynić się do zakończenia lub przynajmniej ograniczenia w tym przedmiocie sporów.

IV. Podsumowując powyższe uwagi, warto kilka słów komentarza poświęcić wspomnianemu już powyżej wyrokowi MTK z 27 sierpnia 2016 r., ponieważ jest to pierwsze orzeczenie tego Trybunału dotyczące indywidualnej odpowiedzialności z tytułu dopuszczenia się zachowania ocenianego jako poważne naruszenie praw i zwyczajów w obrębie ustalonych ram prawa międzynarodowego, majacych zastosowanie do konfliktów zbrojnych, które nie mają charakteru międzynarodowego, skierowanego przeciwko budynkom przeznaczonym na cele religijne, naukowe bądź stanowiące pomniki historyczne (art. 8 ust. 2 lit. e pkt iv Statutu MTK). Z treści orzeczenia, jak i przebiegu postępowania wynika, że toczyło się ono sprawnie i w zasadzie bezproblemowo. Z procesowego punktu widzenia w stadium postępowania przed Izbą Orzekajacca sprawność stanowiła efekt przyznania się do winy przez sprawcę, co pozwoliło uruchomić tryb przewidziany w ar. 65 Statutu MTK, czyli postępowanie w razie przyznania się oskarżonego do winy. W ten sposób znacząco ograniczono konieczność prowadzenia postępowania dowodowego. Niemniej w toku postępowania pojawiły się kwestie sygnalizowane jako kontrowersyjne, ale trafnie zostały rozstrzygnięte, a Trybunał wyraźnie podkreślał, że zbrodnie przeciwko mieniu - bez względu na jego charakter - zawsze będą posiadały inny wymiar aniżeli te skierowane przeciwko ludzkości.

W omawianym postępowaniu oskarżonemu - Ahmadowi Al Mahdiemu zarzucono zniszczenie dziesięciu obiektów o znaczeniu historycznym i naukowym, stanowiących pomniki historii. Zniszczenia dokonane zostały w czerwcu i lipcu 2012 r. w Timbuktu, w warunkach konfliktu zbrojnego o wewnętrznym charakterze na terenie Mali. Koncentrując rozważania na przyjętej kwalifikacji prawnej zarzuconej i przypisanej Al Mahdiemu zbrodni wojennej, w pierwszej kolejności należy odnieść się do oceny charakteru zaatakowanych obiektów. Zniszczeniu uległy mauzolea i groby, z których dziewięć było wpisanych na prowadzoną przez UNESCO Listę Światowego Dziedzictwa. Fakt umieszczenia obiektów na wspomnianej liście przesądzał o ich walorach, ponieważ jak wynika z art. 11 ust. 2 Konwencji w sprawie ochrony światowego dziedzic-

${ }^{29}$ Szerzej E. Ehlert, op. cit., s. 135-137. 
twa kulturalnego i naturalnego ${ }^{30}$ - na Listę Światowego Dziedzictwa moga zostać wpisane obiekty posiadajace jedynie wyjątkową wartość powszechną, która jest określana na podstawie kryteriów ustalonych przez Komitet Światowego Dziedzictwa. Uzasadniając jednak przyjętą kwalifikację prawną w zakresie posiadanych przez zniszczone obiekty wartości, Trybunał odwołał się do pojęcia ochrony specjalnej w wersji, w jakiej została ona zdefiniowana w przywołanych już powyżej w art. 27 i art. 56 IV Konwencji haskiej z 1907 r. oraz Protokołów dodatkowych do Konwencji genewskich z 1949 r., a także pojęcia ochrony wzmocnionej wprowadzonego - jak zauważono powyżej - do II Protokołu do Konwencji z 1954. W rezultacie trzeba przypomnieć, że w przyjętej przez MTK koncepcji wartościowania obiektów budynki nieobjęte ochrona szczególną przez postanowienia wymienionych dokumentów międzynarodowych w zakresie jurysdykcji Trybunału będą objęte ochroną jak inne budowle cywilne. Rozwiązanie to, jak już zresztą wspomniano, przyjęto zarówno wobec konfliktów o charakterze wewnętrznym, jak i międzynarodowym. Trybunał stwierdził też, że dla przypisania odpowiedzialności nie jest istotne, czy czyn popełniony został w trakcie walki czy też poza nia. Istotny jest element w postaci bezpośredniego zamiaru podjęcia ataku i zniszczenia chronionego obiektu. Al Mahdi obecny był przy wszystkich zarzuconych mu atakach, aczkolwiek bezpośrednio - czynnie uczestniczył w zniszczeniu pięciu obiektów, a do zniszczenia pozostałych pięciu przyczynił się zarówno przez podżeganie do ich zniszczenia, jak i pomocnictwo w postaci dostarczenia narzędzi, nagłaśnianie wydarzenia w prasie, szerzenie propagandy religijnej i ideologicznej. W rezultacie w podstawie skazania uwzględniono konsekwencje wynikajace z art. 25 ust. 3 lit. a Statutu MTK, dotyczące współsprawstwa. Ostatecznie wymierzona została kara dziewięciu lat pozbawienia wolności. Kwestia naprawienia szkody pozostała natomiast otwarta - o postępowaniu w tym przedmiocie decydują regulacje przewidziane w art. 75 Statutu MTK.

Z dotychczasowego orzecznictwa Trybunału wynika, że przyznawane kompensaty to raczej symboliczne kwoty, co m.in. można stwierdzić na podstawie decyzji w sprawie pochodzacego z Demokratycznej Republiki Konga zbrodniarza wojennego Germaina Katangi. W orzeczeniu ogłoszonym 24 marca 2017 r. przez II Izbę Orzekająca MTK ofiarom zbrodni popełnionych przez Katange 24 lutego 2003 r., podczas ataku na położoną w Demokratycznej Republice Konga miejscowość Bogoro, przyznano kompensaty za doznane krzywdy i straty w wysokości 250 USD $^{31}$. Jest oczywiste, że kwota ta w żaden sposób nie jest w stanie zrekompensować doznanych cierpień, z kolei w kontekście ochrony dóbr o znaczeniu dla światowego dziedzictwa nie ulega wątpliwości, że żadna decyzja kompensacyjna nie może przywrócić istnienia bezcennych obiektów utraconych w trakcie działań wojennych i w wyniku podejmowania bezmyślnych decyzji.

Oceniając zatem skutki usamodzielnienia w obrębie międzynarodowej ochrony dóbr kulturalnych w okresie konfliktów zbrojnych kwestii ścigania

${ }^{30}$ Konwencja w sprawie ochrony światowego dziedzictwa kulturalnego i naturalnego przyjęta w Paryżu 16 listopada 1972 r. (Dz. U. 1976, Nr 32, poz. 190).

31 ICC-01/04-01/07, http//icc-cpi.int/drc/katanga\#. 
sprawców zbrodni przeciwko dobrom kultury, z uznaniem należy podkreślić, że: po pierwsze, do kategorii przestępstw zaliczono nie tylko czyny popełniane w okresie konfliktów międzynarodowych, lecz także i w czasie konfliktów wewnętrznych, po drugie, odpowiedzialność sprawców możliwa jest wyłącznie w warunkach świadomego działania skierowanego przeciwko dobrom o znaczeniu dla światowego dziedzictwa kulturalnego.

Mając z kolei na względzie fakt, że II Protokół do Konwencji z 1954 i Statut MTK powstawały w zbliżonym okresie, przy braku współpracy między autorami wskazanych dokumentów, w sferze postulatów na tle przyjętych rozwiązań za aktualne należy uznać następujące kwestie:

1) potrzebę ujednolicenia katalogów przestępstw przeciwko dobrom kulturalnym wymienionym w Statucie MTK i w II Protokole do Konwencji z 1954, i oparcie ich ochrony na wartościach, jakie uwzględnione zostały w Konwencji z 1954, a także zachowanie przyjętej w wskazanej Konwencji terminologii. Statut niepotrzebnie bowiem korzysta z słownictwa regulaminów haskich z 1907 r. i Konwencji genewskich z 1949 r., skoro funkcjonuje dokument późniejszy o uniwersalnym charakterze, którym jest Konwencja haska z 1954 r. Niechęć USA i Wielkiej Brytanii do Konwencji haskiej z 1954 r. nie powinna osłabiać jej roli w prawie międzynarodowym;

2) pożądane jest także wyraźnie objęcie ściganiem na gruncie postanowień Statutu MTK zbrodni skierowanych przeciwko dobrom o szczególnym znaczeniu dla światowego dziedzictwa, stanowiącym ruchomości, obecnie ochrona ta wyartykułowana została jedynie wobec obiektów stanowiących nieruchomości;

3) pojęcia „konieczność wojskowa” oraz „cel wojskowy” wymagają zdefiniowania w obrębie prawa karnego, skoro uwzględniają je postanowienia Statutu MTK, które wiążą je bezpośrednio z kwestią odpowiedzialności karnej.

dr hab. Anna Gerecka-Żotyńska

Uniwersytet im. Adama Mickiewicza w Poznaniu

CRIMINAL-LAW LIABILITY OF PERPETRATORS OF CRIMES AGAINST CULTURAL GOODS COMMITTED DURING ARMED CONFLICTS AS PART OF THE INTERNATIONAL PROTECTION OF THE WORLD CULTURAL HERITAGE

\section{Summary}

The article presents two international documents produced in the last decade of the twentieth century, the adoption of which was intended to contribute, among other things, to a more effective protection of cultural assets in times of armed conflicts. The increase in their effectiveness was mainly the result of distinguishing individual criminal liability of perpetrators of offences against cultural property by national and international jurisdictions. Accordingly, the provisions of Second Protocol to the Hague Convention of 1954 for the Protection of Cultural Property in the Event of Armed Conflict (1999) and the provisions of the Statutes of the International Criminal Court have been duly discussed. Attention was drawn to the similarities and differences in these documents which allow to eliminate the existing legal loopholes and the still unsatisfactory level of protection of cultural goods in times of armed conflicts. 
